Crewther, W. G. \& McQuade, A. B. (1955). J. gen. Microbiol. 12, 311-313

\title{
The Intestinal Microflora of the Glothes Moth Larva Tineola bisselliella in relation to Wool Digestion
}

\author{
By W. G. CREWTHER AND A. B. MCQUADE \\ Biochemistry Unit, Wool Textile Research Laboratory, C.S.I.R.O., \\ Melbourne, Australia
}

SUMMARY: The intestines of clothes moth larvae, Tineola bisselliella, examined usually contained very few micro-organisms; this may be related to the high $\mathbf{p H}$ values of the intestinal contents. It was concluded that bacteria play no part in the digestion of wool by these larvae.

It was shown by Linderstrøm-Lang \& Duspiva (1936) and by Waterhouse (1952) that the mid-gut of the clothes moth larva, Tineola bisselliella, has a reduction potential of $c .-250 \mathrm{mV}$, at $\mathrm{pH}$ values near 10 . These reducing conditions, thought to assist the digestion of keratin, might result from the metabolic processes of micro-organisms within the intestine. We therefore examined the intestinal microflora of the moth larvae.

\section{METHODS}

Larvae were obtained from laboratory cultures growing on unsterilized lactic casein powder (90-mesh) containing $10 \%$ dried yeast powder, and from naturally occurring colonies on greasy wool. Laboratory cultures on wool were obtained by transference of larvae or eggs from casein medium to greasy wool and incubation at the optimal temperature of $28^{\circ}$. Larval intestines were withdrawn aseptically after circular incision of the skin near the head and amputation of the tail tip.

Emulsions of four to six intestines in $0.05 \mathrm{ml}$. peptone water were equally distributed on six plates of nutrient agar containing $1 \%(\mathrm{w} / \mathrm{v})$ glucose and $0.5 \%(\mathrm{w} / \mathrm{v})$ yeast extract adjusted to $\mathrm{pH}$ values $7 \cdot 5,8.5$ and 9.5 . Plates were incubated aerobically and anaerobically at $28^{\circ}$.

\section{RESULTS}

Table 1 shows that with few exceptions the bacterial population in the gut, particularly in the mid- and hind-gut, was very small. This was confirmed by microscopic examination of smears of the gut contents which in general appeared to be free from bacteria. Smears of gut contents from larvae grown on wool consisted largely of partly degraded cortical cells and of other wool debris.

The larvae with high intestinal counts of bacteria (Table 1) were all derived from a single culture of larvae on casein medium and were shown by plating and by direct microscopic examination to be heavily infected with Grampositive cocci. Other larval colonies on casein, however, were not infected in 
this way. On transferring infected larvae to greasy wool the infection persisted indefinitely. In pure culture the coccus grew optimally at $28^{\circ}$, formed white colonies aerobically on nutrient agar, and anaerobically, slowly, a translucent growth. This coccus was catalase-positive, coagulase-negative (rabbit plasma), gave an acid clot in litmus milk, acid but no gas from glucose, produced no acetoin, and according to the classification of Shaw, Stitt \& Cowan (1951) belonged to the Staphylococcus lactis group of organisms which are often found in dairy products.

Table 1. Micro-organisms in the gut of Tineola larvae

\begin{tabular}{|c|c|c|c|}
\hline Source of larvae & $\begin{array}{c}\text { Growth of } \\
\text { micro-organisms }\end{array}$ & $\begin{array}{l}\text { pH value } \\
\text { of medium }\end{array}$ & Total count/gut \\
\hline $\begin{array}{l}\text { Casein culture (C.S.I.R.O. } \\
\text { Geelong) }\end{array}$ & $\begin{array}{l}\text { Aerobic } \\
\text { Anaerobic }\end{array}$ & $\begin{array}{l}8 \cdot 5 \\
8 \cdot 5\end{array}$ & $\begin{array}{l}\text { Many staphylococci } \\
\text { Many staphylococei }\end{array}$ \\
\hline $\begin{array}{l}\text { Casein culture (C.S.I.R.O. } \\
\text { Canberra) }\end{array}$ & $\begin{array}{l}\text { Aerobic } \\
\text { Aerobic } \\
\text { Aerobic } \\
\text { Anaerobic } \\
\text { Anaerobic } \\
\text { Anaerobic }\end{array}$ & $\begin{array}{l}7 \cdot 5 \\
8 \cdot 5 \\
9 \cdot 5 \\
7 \cdot 5 \\
8 \cdot 5 \\
9 \cdot 5\end{array}$ & $\begin{array}{r}1 \\
120 \\
12 \\
\text { Spreader } \\
0 \\
1\end{array}$ \\
\hline Casein culture (Melbourne) & $\begin{array}{l}\text { Aerobic } \\
\text { Aerobic } \\
\text { Aerobic } \\
\text { Anaerobic } \\
\text { Anaerobic } \\
\text { Anaerobic }\end{array}$ & $\begin{array}{l}7 \cdot 5 \\
8 \cdot 5 \\
9 \cdot 5 \\
7 \cdot 5 \\
8 \cdot 5 \\
9 \cdot 5\end{array}$ & $\begin{array}{l}\mathbf{3} \\
\mathbf{1} \\
\mathbf{7} \\
\mathbf{0} \\
\mathbf{0} \\
\mathbf{0}\end{array}$ \\
\hline $\begin{array}{l}\text { Wool culture (C.S.I.R.O. } \\
\text { Canberra) }\end{array}$ & $\begin{array}{l}\text { Aerobic } \\
\text { Aerobic } \\
\text { Aerobic } \\
\text { Anaerobic }\end{array}$ & $\begin{array}{l}7 \cdot 5 \\
8 \cdot 5 \\
9 \cdot 5 \\
8 \cdot 5\end{array}$ & $\begin{array}{l}5 \\
7 \\
5 \\
0\end{array}$ \\
\hline Wool culture (Melbourne) & $\begin{array}{l}\text { Aerobic } \\
\text { Aerobic } \\
\text { Aerobic } \\
\text { Anaerobic } \\
\text { Anaerobic } \\
\text { Anaerobic }\end{array}$ & $\begin{array}{l}7 \cdot 5 \\
8 \cdot 5 \\
9 \cdot 5 \\
7 \cdot 5 \\
8 \cdot 5 \\
9 \cdot 5\end{array}$ & $\begin{array}{l}\text { Overgrown with fungi } \\
\text { Overgrown with fungi } \\
\text { Overgrown with fungi } \\
0 \\
1 \\
40\end{array}$ \\
\hline Wild culture (greasy wool) & $\begin{array}{l}\text { Aerobic } \\
\text { Anaerobic }\end{array}$ & $\begin{array}{l}7 \cdot 5 \\
7 \cdot 5\end{array}$ & $\begin{array}{l}\mathbf{0} \\
\mathbf{0}\end{array}$ \\
\hline
\end{tabular}

Only one colony developed (aerobically) on six plates inoculated with an emulsion of mid/lower guts from larvae on casein medium.

As the mid-gut has a $\mathrm{pH}$ value of about 10.0 (Duspiva, 1936; LinderstrømLang \& Duspiva, 1936; Waterhouse, 1952) the growth of the isolated coccus over a range of different initial $\mathrm{pH}$ values was compared with that of a culture having the same physiological properties but which was derived from a different source (supplied by the Department of Bacteriology, University of Melbourne). The organisms were incubated at $28^{\circ}$ in a $\mathrm{CO}_{2}$-free atmosphere in a medium containing: $1.0 \%(\mathrm{w} / \mathrm{v})$ peptone (Difco); $0.1 \%(\mathrm{w} / \mathrm{v})$ yeast extract (Difco); mineral salts; $0 \cdot 15 \% \mathrm{Na}_{2} \mathrm{HPO}_{4}(\mathrm{w} / \mathrm{v}$ ) buffer. Both strains grew well in $24 \mathrm{hr}$. at initial $\mathrm{pH}$ values in the range $7 \cdot 0-10 \cdot 0$; neither grew at pH 10.5. These results contrast with those of Dernby (1921), who recorded 
a pH range of 5.6-8.1 for the growth of an organism called Staphylococcus blanc at an unspecified temperature. Beveridge (1940) showed that certain haemolytic staphylococci from milk were alkali tolerant.

\section{CONCLUSION}

The bacterial population in the gut of most of the Tineola bisselliella larvae studied was too small to influence the oxidation-reduction potential of the gut contents or to assist in the digestion of wool; it is concluded that bacteria play no essential part in this process. The high intestinal $\mathrm{pH}$ value is probably an important factor in the suppression of bacterial growth in the gut.

\section{REFERENCES}

BEVERIDGE, W. I. B. (1940). An alkaline culture medium for differentiation of staphylococci and micrococci from cows' milk. Aust. J. exp. Biol. med. Sci. 18, 391.

DeRnBy, K. G. (1921). La concentration optimale en ions hydrogène favorisant le développement de certains microorganismes. Ann. Inst. Pasteur, 35, 277.

Duspiva, F. (1936). Die Verwendung der Glaselektrode zur Bestimmung der $\mathrm{H}^{+}$-Koncentration im Darmsaft der Kleider- und Wachsmottenlarven. C.R.Lab. Carlsberg, 21, 167.

Linderstrøm-Lang, K. \& Duspiva, F. (1936). Studies on enzymatic histochemistry. Pt. XVI. Digestion of keratin by the larvae of the clothes moth Tineola bisselliella (Humm). C.R. Lab. Carlsberg, 21, 53.

Shaw, C., Stitt, J. M. \& Cowan, S. T. (1951). Staphylococci and their classification. J. gen. Microbiol. 5, 1010.

Waterhouse, D. F. (1952). Studies on digestion of wool by insects. Pt. VI. The pH and oxidation-reduction potential of the alimentary canal of the clothes moth larva (Tineola bisselliella Humm.). Aust. J. sci. Res. B, 5, 178. 